\title{
Obtaining and characterization of monoclonal antibodies against capsular polysaccharides of Streptococcus pneumoniae serotype 1, 5, 6B, 14 and $19 \mathrm{~F}$

\author{
Obtención y caracterización de anticuerpos monoclonales contra polisacáridos capsulares \\ de Streptococcus pneumoniae serotipo 1, 5, 6B, 14 y 19F
}

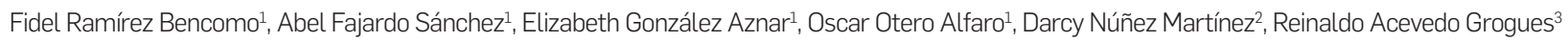

DOI. 10.21931/RB/2018.03.01.4

\begin{abstract}
Five monoclonal antibodies named 2B5B10, 2E4D11, 1D12E10, 1D1D11 and 177/10/27/11 were produced against capsular polysaccharides of Streptococcus pneumoniae serotypes 1, 5, 6B, 14 and 19F respectively. They all were obtained by hybridoma technology and produced by in vivo procedures. Were purified by Protein A-based Affinity Chromatography and the yield of all processes was around the 2.9 and $3.7 \mathrm{mg}$ per $\mathrm{mL}$ of ascitic fluid; and with a high purity (over $90 \%$ in all cases). All MAbs only reacted against their homologue polysaccharide showing no cross reactivity against other serogroups. The affinity constants (Kaff) measured by non-competitive ELISA were $3.08 \times 10^{11} \mathrm{M}^{-1}$ for 2B5B10, $1.53 \times 10^{12} \mathrm{M}^{-1}$ for $2 \mathrm{E} 4 \mathrm{D} 11,8.68 \times 10^{10} \mathrm{M}^{-1}$ for 1D12E10, $1.42 \times 10^{13} \mathrm{M}^{-1}$ for 1D1D11 and $7.2109 \mathrm{M}-1$ for 177/10/27/11. The potential application of these MAbs for identity tests was demonstrated by their abilities of no cross-react with the other purified PS presents in QuimiVio, through indirect ELISA
\end{abstract}

Keywords: monoclonal antibodies, Streptococcus pneumoniae, identity tests, ELISA

Resumen: Se produjeron cinco anticuerpos monoclonales denominados 2B5B10, 2E4D11, 1D12E10 y 1 D1D11 contra los polisacáridos capsulares de los serotipos 1, 5, 6B y 14 de Streptococcus pneumoniae, respectivamente. Todos fueron obtenidos por la tecnología del hibridoma y producidos por procedimientos in vivo. Se purificaron mediante cromatografía de afinidad basada en proteína A y el rendimiento de todos los procesos fue de alrededor de 2,9 y 3,7 mg por ml de líquido ascítico; y con una alta pureza (más del $90 \%$ en todos los casos). Todos los anticuerpos monoclonales solo reaccionaron contra su polisacárido homólogo que no muestra reactividad cruzada contra otros serogrupos. Las constantes de afinidad (Kaff) medidas por ELISA no

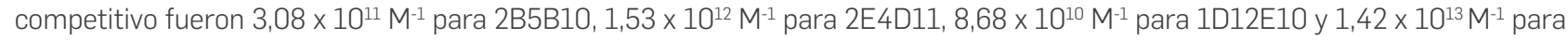
1D1D11. La posible aplicación de estos anticuerpos monoclonales para ensayos de identidad se demostró por su capacidad de no tener entrecruzamientos con los otros polisacáridos purificados presentes en QuimiVio, a través de ELISA indirecto.

Palabras clave: anticuerpos monoclonales, Streptococcus pneumoniae, ensayos de identidad, ELISA

\section{Introduction}

Streptococcus pneumoniae bacterial infections are responsible for the majority of mortality and morbidity seen in the extremes of age, young children ( $<2$ years) and elderly ${ }^{1-3}$. The critical virulence factor of the bacteria is the capsular polysaccharide (PS), and based on it, there are recognized more than 90 serotypes ${ }^{4,5}$. The increasing number of antibioticresistant strains and the severity of pneumococcal diseases, make vaccination the most effective intervention ${ }^{6,7}$. Currently, there are four licensed vaccines available on the market to prevent this disease, all are based on the PS conjugated or not. (Table 1$)^{8}$ Similarly, there are other several pneumococcal vaccines in research and development state and others even in clinical trial ${ }^{8,9}$. QuimiVio, the cuban PCV vaccine, is a 7-valent vaccine, developed at Finlay Institute, which it is under clinical trial. QuimiVio is composed by PS 1, 5, 6B, 14, 18C, 19F and 23F conjugated all to tetanus toxoid (TT) and adsorbed on aluminum phosphate (AlPO4). The vaccine coverage is according to the $S$. pneumoniae serotype circulating in Cuba ${ }^{10,11}$.

Production and manufacturing of these complex multi- serotype polysaccharide conjugate vaccines are very difficult and challenging. Rigorous analytical characterization and the standard release and stability assays are required ${ }^{12}$. The World Health Organization (WHO) and Pharmacopoeia institutes provide guidance and recommendations on the type of release, stability, and characterization testing that should be performed at a minimum ${ }^{13}$. One of those critical tests are the identity and quantitation of each polysaccharide serotype including the carrier protein, in the multivalent formulation. So, to ensure the analytical techniques that allow carrying out the quality controls of this type of vaccine is without a doubt a very important aspect. Analytical techniques that been simple and rapid to perform and at the same time sufficiently specific ${ }^{14}$. In this respect, monoclonal antibodies (MAbs) have become a powerful analytical tool that have allowed, in polysaccharide vaccines like Haemophilus influenzae $b$ Tetanus toxoid conjugate vaccines and in multivalent antimeningococcal polysaccharide vaccines, determine the content and the identity of PS $15-17$.

\footnotetext{
${ }^{1}$ Monoclonal Antibodies Laboratory, Department of Biological Evaluation, Research Area, Finlay Vaccines Institute. Havana, Cub

${ }^{2}$ Animal Models Department, Research Area, Finlay Vaccines Institute, Havana, Cuba

${ }^{3}$ Department of Biological Evaluation, Research Area, Finlay Vaccines Institute. Havana, Cuba

Author e-mail: framirez@finlay.edu.cu
} 
Table 1. Pneumococcal licensed vaccines

\begin{tabular}{|c|c|c|}
\hline $\begin{array}{c}\text { Generic Name } \\
\text { Pneumococcal } \\
\text { conjugate } \\
\text { vaccine (PCV) }\end{array}$ & $\begin{array}{c}\text { Prevnar (7-valent) } \\
\text { (Pfizer) }\end{array}$ & $\begin{array}{c}\text { 4, 6B, 9V, 14, 18C, 19F, and 23F conjugated to the } \\
\text { nontoxic variant of diphtheria toxin (CRM197) }\end{array}$ \\
\cline { 2 - 3 } & $\begin{array}{c}\text { Prevnar 13 (13-valent) } \\
\text { (Pfizer) }\end{array}$ & $\begin{array}{c}1,3,4,5,6 \mathrm{~A}, 6 \mathrm{~B}, 7 \mathrm{~F}, 9 \mathrm{~V}, 14,18 \mathrm{C}, 19 \mathrm{~A}, 19 \mathrm{~F} \text { and } \\
23 \mathrm{~F} \text { conjugated to CRM197 }\end{array}$ \\
\cline { 2 - 3 } & $\begin{array}{c}\text { Synflorix (10-valent) } \\
\text { (GlaxoSmithKline) }\end{array}$ & $\begin{array}{c}1,3,4,5,6 \mathrm{~B}, 7 \mathrm{~F}, 9 \mathrm{~V}, 14,18 \mathrm{C}, 19 \mathrm{~F} \text { and 23F all } \\
\text { conjugated to protein D (derived from non-typeable } \\
\text { Haemophilus influenzae) except 18C and 19F that } \\
\text { are conjugated to tetanus (TT) and diphtheria } \\
\text { toxoid (DT) respectively }\end{array}$ \\
\hline $\begin{array}{c}\text { Pneumococcal } \\
\text { polysaccharide } \\
\text { vaccine (PPV) }\end{array}$ & $\begin{array}{c}\text { Pneumovax (23-valent) } \\
\text { (Merck) }\end{array}$ & $\begin{array}{c}1,2,3,4,5,6 \mathrm{~B}, 7 \mathrm{~F}, 8,9 \mathrm{~N}, 9 \mathrm{~V}, 10 \mathrm{~A}, 11 \mathrm{~A}, 12 \mathrm{~F}, 14,15 \mathrm{~B}, 17 \mathrm{~F} \\
, 18 \mathrm{C}, 19 \mathrm{~A}, 19 \mathrm{~F}, 20,22 \mathrm{~F}, 23 \mathrm{~F} \text { and 33F }\end{array}$ \\
\hline
\end{tabular}

This paper describes the obtaining, production, purification and characterization of five MAbs against the capsular polysaccharides from S. pneumoniae serotypes 1, 5, 6B, 14 and 19F, which could have application in analytical assays for determine the identity of the PS in QuimiVio vaccine.

\section{Materials and methods}

\section{Reagents and buffers}

Buffers: Phosphate-buffered saline (PBS) $(140 \mathrm{mM} \mathrm{NaCl}$ $2.7 \mathrm{mM} \mathrm{KCl}, 10 \mathrm{mM} \mathrm{Na}_{2} \mathrm{HPO}_{4}, 1.8 \mathrm{mM} \mathrm{KH}_{2} \mathrm{PO}_{4}, \mathrm{pH}$ 7.4), blocking buffer (PBS, 3\% non-fat dried milk), washing solution (PBS, $0.05 \%$ (v/v) Tween 20, pH 7.4), substrate buffer (orthophenylenediamine (OPD), $35 \mathrm{mM}$ citric acid, $67 \mathrm{mM} \mathrm{Na}_{2} \mathrm{HPO}_{4}, 0.012 \%$ (w/v) $\left.\mathrm{H}_{2} \mathrm{O}_{2}, \mathrm{pH} 5.0\right)$, stop solution $\left(2,5 \mathrm{M} \mathrm{H}_{2} \mathrm{SO}_{4}\right)$.

Antigens: Plain purified capsular polysaccharide (PS) from S. pneumoniae serotypes 1, 5, 6A, 6B, 14, 18C, 19A, 19F, 23F and Polysaccharide C (Finlay Institute, Cuba); Tetanus toxoid (TT) (Finlay Institute, Cuba). Capsular polysaccharides from serotypes 1, 5, 6B, 14 and 19F conjugated to TT (PS1-TT, PS5TT, PS6B-TT, PS14-TT and PS19F-TT) (Finlay Institute, Cuba)

Conjugated antibodies: sheep anti mouse IgG whole molecule conjugated to horseradish peroxidase. (Sigma-Aldrich, USA).

Mouse Monoclonal Antibody Isotyping Kit. Bio-Rad, USA.

Chromatographic columns and supports: Column HiTrap rProtein A Fast Flow. Bed Volume: 5 mL. Column: XK 16/20; Support: Sephadex G 25 M. Bed volume: 30 mL.

Table 2. Immunization protocols

\section{Animals}

All experiments were performed in BALB/c mice of 6-8 weeks of age and 18-20 g of body weight, obtained from the Center for the Production of Laboratory Animals (CENPALAB, Havana, Cuba). The animals were kept under controlled conditions of temperature $\left(21-24^{\circ} \mathrm{C}\right)$, humidity $(20-25 \%)$, alternating cycles of light/dark for 12 hours, and received food and water acidulated with $\mathrm{HCl} \mathrm{pH} 2.5$ ad libitum. The handling of these animals was performed according to established institutional norms, according to the Guide for the Care and Use of Laboratory Animals ${ }^{18}$.

\section{Generation and selection of hybrids against PS-14 from S. pneumonia}

\section{Immunization Protocol}

Five groups of five female BALB/c mice were immunized subcutaneously with each polysaccharide emulsified $\mathrm{v} / \mathrm{v}$ with Freund's complete adjuvant. Booster doses were given at 14-days interval with same concentration of immunogen but emulsified in Freund's incomplete adjuvant. Total number of doses administered was depending on the capacity of the immunogen to generate an antibody response in the animals. In order to determine it, blood samples were taken seven days after each immunization, from the third dose administered. Serum titers were checked by ELISA during the immunization schedule as described below. After obtaining the required antibody titers and 3 days before planned fusion process, a final intravenously booster of plain polysaccharide (same concen-

\begin{tabular}{|c|c|c|c|c|c|}
\hline IP & MAb & Antigen & Doses & Via & Scheme \\
\hline 1 & Anti-PS1 & $\begin{array}{l}\text { PS1-TT, lot 001.15.01 with } \\
\text { Freund's complete adjuvant }\end{array}$ & $10 \mu \mathrm{g}$ & Subcutaneous & $\begin{array}{l}\text { Three doses } \\
(0,14,28)\end{array}$ \\
\hline 2 & Anti-PS5 & $\begin{array}{l}\text { PS5-TT, lot 005.15.01 with } \\
\text { Freund's complete adjuvant }\end{array}$ & $10 \mu \mathrm{g}$ & & $\begin{array}{l}\text { Three doses } \\
(0,14,28)\end{array}$ \\
\hline 3 & Anti-PS6B & $\begin{array}{l}\text { PS6B-TT, lot 06B.15.01 with } \\
\text { Freund's complete adjuvant }\end{array}$ & $20 \mu \mathrm{g}$ & & $\begin{array}{c}\text { Five doses } \\
(0,14,28,42,56)\end{array}$ \\
\hline 4 & Anti-PS14 & $\begin{array}{l}\text { PS14-TT, lot } 014.15 .01 \text { with } \\
\text { Freund's complete adjuvant }\end{array}$ & $5 \mu \mathrm{g}$ & & $\begin{array}{l}\text { Three doses } \\
(0,14,28)\end{array}$ \\
\hline 5 & Anti-PS19F & $\begin{array}{c}\text { PS19F joined to pearls of } \\
\text { polyhydroxyalkanoate (PhA) }\end{array}$ & $20 \mu \mathrm{g}$ & & $\begin{array}{l}\text { Three doses } \\
(0,14,28)\end{array}$ \\
\hline
\end{tabular}


tration) without adjuvant was administered to mice which who had higher values of antibodies titers. Table 2 summarizes the different schemes followed in the different cases.

\section{Mouse serum titrations}

Mouse serum titrations were performed by an indirect Enzyme-linked Immunosorbent Assay (ELISA). The plate (Maxisorp, Nunc, Denmark) was coated with $10 \mu \mathrm{g} / \mathrm{mL}$ of purified $\mathrm{PsC}$ in PBS and incubated at $4^{\circ} \mathrm{C}$ overnight. Then the plate was incubated with blocking buffer at $37^{\circ} \mathrm{C}$ for $1 \mathrm{hr}$. After, mouse sera (in two-fold serial dilutions starting from 1:1000 to $1: 32000$ in PBS) were added and incubated for $2 \mathrm{~h}$ at $37^{\circ} \mathrm{C}$. Subsequently, sheep anti mouse lgG dilution 1:1000 in washing solution with skimmed milk (1\%) was added to the wells and incubated for $1 \mathrm{~h}$ at room temperature. After every step the plate was washed three times with washing solution, except after the conjugate, that was washed four times. Substrate buffer was added to each well and the plates were incubated at room temperature in the dark. After $15 \mathrm{~min}$, the reaction was stopped by adding stop solution to each well. The Optical Density (OD) of the reactions was measured at $492 \mathrm{~nm}$ (OD$492 \mathrm{~nm}$ ) in a Multiskan Microplate Reader (Thermo Scientific, USA). Mice with antibodies titers values over dilution 1:8000 were selected for fusion.

\section{Fusion and hybrid screening}

Three days after the final booster, mice with higher titers were euthanized and the spleen removed to use as a source of cells for fusion with Sp2/0 myeloma cells (ratio 10:1) following the protocol described by Köhler and Milstein in $1975^{19}$

After the fusion process, several selection steps were performed with the aim of determine the more specific hybrid. The screening was carried out by indirect ELISA, analogous to the one used in serum titration. In this case plates were coated with $10 \mu \mathrm{g} / \mathrm{mL}$ of each PS and TT individually and as sample $100 \mu \mathrm{L} /$ well of undiluted culture supernatant was used. Hybrids were considered positive when OD492nm was twice the negative control (pre-immune mice serum). The hybrids that secretes the most specific Ab (highest OD against PS and lowest against the carrier TT), and also were of IgG isotype, (see isotype determination) were selected for cloning by limiting dilution technique. After cloning the hybrids were selected based on: growth form (single clone that covers the $3 / 4$ or more of the culture well) and MAb produced exhibit the highest response against their homologous PS and none against the carrier TT.

\section{Isotype determination}

The isotype was determined by Mouse Monoclonal Antibody Isotyping Kit, following manufacturer instructions, from supernatant of selected-as-positive growing hybridomas.

\section{MAb Production}

For producing MAb, an in vivo method was chosen. Selected clones were injected intraperitoneally in a concentration of $1 \times 10^{6}$ cells $/ \mathrm{mL}$ into Pristane-primed mice to obtain ascites. Five days after the administration, mice were investigated daily for production of ascitic fluid (AF). When the abdomens of the mice were enlarged, and their skins were extended, the AF were obtained by intraperitoneal puncture using 19 gauge needles and centrifuged at $12000 \mathrm{rpm}$ for five min. The related supernatants were collected and tittered by indirect ELISA similar to described above. In this case AF was employed as sample in two-fold serial dilutions starting from 1:1000 to 1:1024000 in PBS.

\section{Purification and characterization of MAbs}

MAbs were purified from ascites by affinity chromatography using a HiTrap rProtein A Fast Flow column following manufacturer's instructions. Table shows the different recommended protocols for the most common subclasses.

Specific fraction (S.F.) was later desalted versus PBS in a Sephadex G-25 column. Total protein concentration in S.F was quantified by the bicinchoninic acid reaction ${ }^{20}$ using the Bicinchoninic Acid Protein Assay Kit (Sigma - Aldrich, USA) and Bovine Serum Albumin (BSA) as standard. Sample was replicated three times in appropriated dilutions for fixing to the standard curve. Productivity of the purification process was estimated and expressed as milligrams of MAb per milliliter of ascites. Purity was assessed by SDS-PAGE under reducing conditions on $12.5 \%$ polyacrylamide ge ${ }^{21}$ followed by densitometric analysis using Quantity One software (Bio-Rad). MAb isotype was determined again to corroborate the results. The affinity constant (Kaff) was determined by indirect ELISA, following the method described by Beatty et al. ${ }^{22}$. Cross reactivity of MAb was evaluated by indirect ELISA similar to the one used in mice serum titrations but in this case $10 \mu \mathrm{g} / \mathrm{mL}$ of purified PS from S. pneumoniae serotypes 1, 5, 6A, 6B, 14, 18C, 19A, 19F, 23F, Polysaccharide C and TT were used for coating step and purified MAb at $10 \mu \mathrm{g} / \mathrm{mL}$ in PBS was used as sample. The rest of the procedure was the same.

\section{Results}

\section{Generation of hybrids producing MAbs against PS from S. \\ pneumoniae}

In the process of obtaining a hybrid producer of MAb, immunization is the initial step in obtaining the needed antigen-activated lymphocytes for the fusion process. Several in vivo immunization protocols are often successful and have been described previously ${ }^{23}$.

\section{Fusion and Hybrid selection}

On fusion day, spleens from mice selected were extracted and the fusion procedure was performed following the protocol described by Köhler and Milstein in $1975^{19}$.

After fusion, three selection steps were carried out to select the hybrids that secrete the most specific Ab (highest OD against PS and lowest versus the carrier). At the end of the second selection step, six hybrids were selected against each PS and during the third step, they grew very similarly and all of them showed high response against their homologous PS and lower against TT in the indirect ELISA. They all were producers of IgG class MAbs. The selection was carried out based on the growth form (single clone that covers $3 / 4$ or more of the culture well) and the specificity of the response. The results are shown in Table 3.

Selected hybrids had a response against their homologous PS, significantly higher $(p<0.0001)$ than the serum of the immunized animals, and a response against TT similar to the obtained for the negative control antibody. These hybrids also grew as a single clone, within hours occupied $100 \%$ of the well surface. Those were the conditions for the selection of the clones.

\section{Production of murine MAbs against Capsular Polysaccharide from Streptococcus pneumoniae}

For growing cells and producing MAbs, an in vivo procedure was selected. Twenty Pristane-primed mice, in five groups, 
Table 3. Protein A purification protocols based in the different subclasses

\begin{tabular}{|c|c|c|c|}
\hline \multirow[t]{2}{*}{ Solutions } & \multicolumn{3}{|c|}{ Monoclonal Antibodies } \\
\hline & IgG1 & IgG2a & IgG2b \\
\hline Union Buffer & $\begin{array}{c}\text { Glycine } 1.5 \mathrm{M}, \\
\mathrm{NaCl} 3 \mathrm{M} \mathrm{pH} 8.9\end{array}$ & \multicolumn{2}{|r|}{ PBS pH 7.4} \\
\hline Elution Buffer & $\begin{array}{l}\text { Citric Acid } \\
0.1 \mathrm{M} \mathrm{pH} 6\end{array}$ & $\begin{array}{l}\text { Citric Acid } \\
0.1 \mathrm{M} \mathrm{pH} 5\end{array}$ & $\begin{array}{l}\text { Citric Acid } 0.1 \mathrm{M} \mathrm{pH} 6 \\
\text { Citric Acid } 0.1 \mathrm{M} \mathrm{pH} 3\end{array}$ \\
\hline Neutralization Buffer & Not needed & \multicolumn{2}{|c|}{ Tris $0.1 \mathrm{M} \mathrm{pH} 8$} \\
\hline $\begin{array}{c}\text { Column's Regeneration } \\
\text { Buffer }\end{array}$ & \multicolumn{3}{|c|}{ Citric Acid $0.1 \mathrm{M} \mathrm{pH} 3$} \\
\hline
\end{tabular}

Figure 1. Anti PS IgG response in ascites of mice inoculated with hybrids 2B5B10 (1), 2E4D11 (5), 1D12E10 (6B), 1D1D11 (14) and 177/10/27/11 (19F). The titration was performed by indirect ELISA using serial two-fold dilutions beginning with dilution 1: 1000. The negative control (blank) used was non-immunized mouse serum. The results are expressed in optical density (OD)

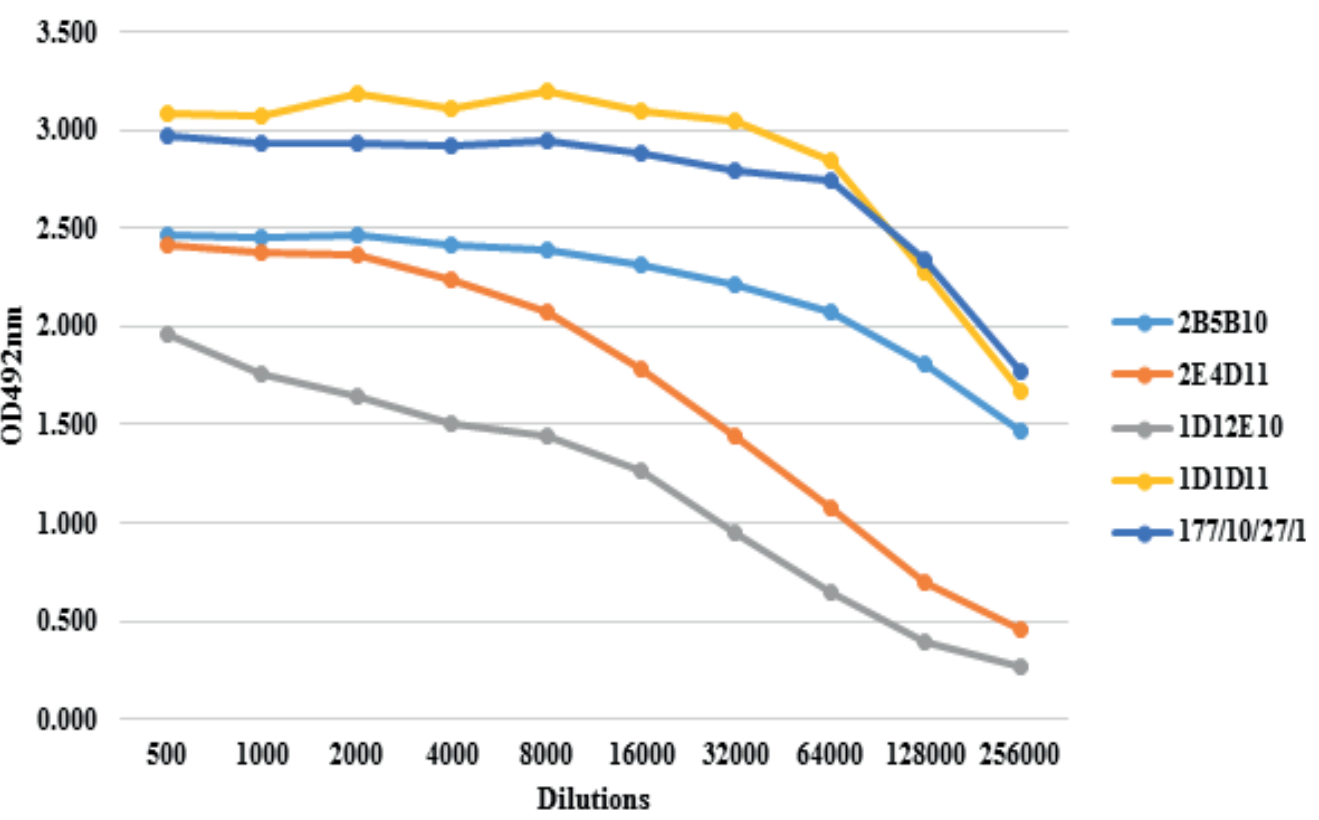

were inoculated with $1 \times 10^{6}$ cells $/ \mathrm{mL}$ of hybridomas selected (Table 2) intraperitoneally to obtain ascites. Fifty (50) $\mathrm{mL}$ of ascites were collected ten days after inoculation from each group.

MAb's titer in ascitic fluid was measured by indirect ELISA method and absorbance (OD) of dilution (Figure 1). These results indicate, that all the hybrids do not produce the same quantity of MAbs, even when they were obtained with similar conditions during in the same fusion process, culture conditions and time of ascites developing.

Ascitic fluid production enriched with the MAb in mice is a quick and profitable method. The amount of injected Pristane and the period between priming with monoclonal cells are both significant factors in ascitic fluid production ${ }^{24,25}$. Furthermore, the number of hybridoma cells injected in the peritoneum of mice is efficient concerning the increased speed of ascitic fluid production. $1 \times 10^{6}$ cells injected in the peritoneum of mice could facilitate the harvest of about 2-3 mL ascitic fluid from each mouse ${ }^{26}$. Some reports indicate that when a cell number of $2.5 \times 10^{7}$ are inoculated, the average life span of mice is 8 days, while a number of $3.2 \times 10^{6}$ extends this time to about 12 days. In these experiments, the ascites is formed faster with increased inoculum, however, a higher inoculum leads to a shorter survival ${ }^{27}$. Current standard protocols often inoculate a number of $1 \times 10^{6}$ cells with an average life expectancy between 17-20 days, a period which enables the extraction of a greater volume of ascites ${ }^{23}$. This was the value selected in this study and achieved a survival rate of 14 days.

Since several liters of RPMI medium and fetal bovine serum (as well as several months of continuous struggle and attention) are required for the production of this amount of antibody by in-vitro method, it seems that the ascites production method is a very valuable and economic method.

On the other hand, during ascites development, animals should be observed at least three times per week for the first week and daily thereafter to monitor the degree of abdominal

Table 4. Fusion Percentage and clones selected in each fusion protocolsubclasses

\begin{tabular}{|c|c|c|c|c|}
\hline FP & MAb & Fusion Percentage & Clone selected & Subclass \\
\hline $\mathbf{1}$ & Anti-PS1 & $100 \%$ & 2B5B10 & IgG2a \\
\hline $\mathbf{2}$ & Anti-PS5 & $100 \%$ & $2 \mathrm{E} 4 \mathrm{D} 11$ & IgG2b \\
\hline $\mathbf{3}$ & Anti-PS6B & $92 \%$ & $1 \mathrm{D} 12 \mathrm{E} 10$ & IgG1 \\
\hline $\mathbf{4}$ & Anti-PS14 & $100 \%$ & $1 \mathrm{D} 1 \mathrm{D} 11$ & IgG1 \\
\hline $\mathbf{5}$ & Anti-PS19F & $61,8 \%$ & $177 / 10 / 27 / 11$ & IgG2b \\
\hline
\end{tabular}


distention and signs of illness ${ }^{28}$. However, in our study, no significant evidence of distress was obtained in the animals.

\section{Purification of MAbs}

One of the disadvantages of in vivo MAb production method, besides the suffering generated in the animals, is the fact that the material obtained (ascites) contains several own contaminants. Albumin, transferrin, proteases, nucleases and even other immunoglobulins (Igs) are typical contaminants of body fluids ${ }^{23}$.

All MAbs were purified by affinity chromatography in a HiTrap rProtein A FF column. Figure 2 shows the chromatographic profiles of purification processes of MAbs 2B5B10 (PS-1, IgG2a), 2E4D11 (PS-5, IgG2b) and 1D12E10 (PS-6B, IgG1). The remain MAbs profiles are not shown because they were very similar to the ones presented as they share subclasses.

As shown in Figure 2.A, the chromatographic profile, of the affinity chromatographic process from all MAbs are very similar, and it is characterized by two well defined peaks. Peak 1 corresponds to the first eluted fraction during the run, the unspecific fraction (UF), generally composed mainly by ascites pollutants which do not bound to the matrix and are eluted quickly. Peak 2 corresponds to the specific fraction (SF), which is retained on the column and eluted by $\mathrm{pH}$ changes after the addition of an elution buffer. Figure 2.B shows the profile obtained from size exclusion chromatography. This desalting step on purified MAbs is very important because it allows the removal of the excess of $\mathrm{NaCl}$ used in the purification, and allows purified MAb to remain in a more favorable conservation state, such as PBS buffer; increasing the stability of the MAbs ${ }^{29}$. In this case, peaks 2 of each purification process are not of the same height, it could be related with the fact that the ascites did not have the same antibody titer.

There are several methods for MAbs purification. Proceedings based on solubility differential like salting out (ammonium or sodium sulphate), caprylic acid or solvent addition, among others, are still used for isolation of fractions containing antibodies. These protocols are suitable for bulk proteins and when high purity is not necessary. Chromatographic methods based on anionic or cationic exchange, hydrophobic interaction, affinity and multi-step-strategies are usually used for reaching fine pure products ${ }^{30,31}$.

In the biopharmaceutical industry, chromatography is a critical and widely used separation and purification technology due to its high resolution. Chromatography exploits the physical and chemical differences between biomolecules for separation. The most of purification processes for MAbs involve Protein A-based chromatography, which results in a high degree of purity and recovery in a single step ${ }^{32}$.

Protein A is a bacterial protein from Staphylococcus aureus which naturally interacts with the Fc fragment of antibodies. The high affinity of Protein A for the Fc region of IgG-type

Figura 2. Chromatographic profiles of the purification process (From Left to Right). Affinity chromatography of MAbs 2 B5B10 (PS-1, IgG2a), 2E4D11 (PS-5, IgG2b) and 1D12E10 (PS-6B, IgG1), using HiTrap rProtein A Fast Flow column respectively (Peak 1: Unspecific Fraction. Peak 2: Specific Fraction). Size exclusion chromatography of the specified fraction of MAb 2B5B10 (Desalting process).
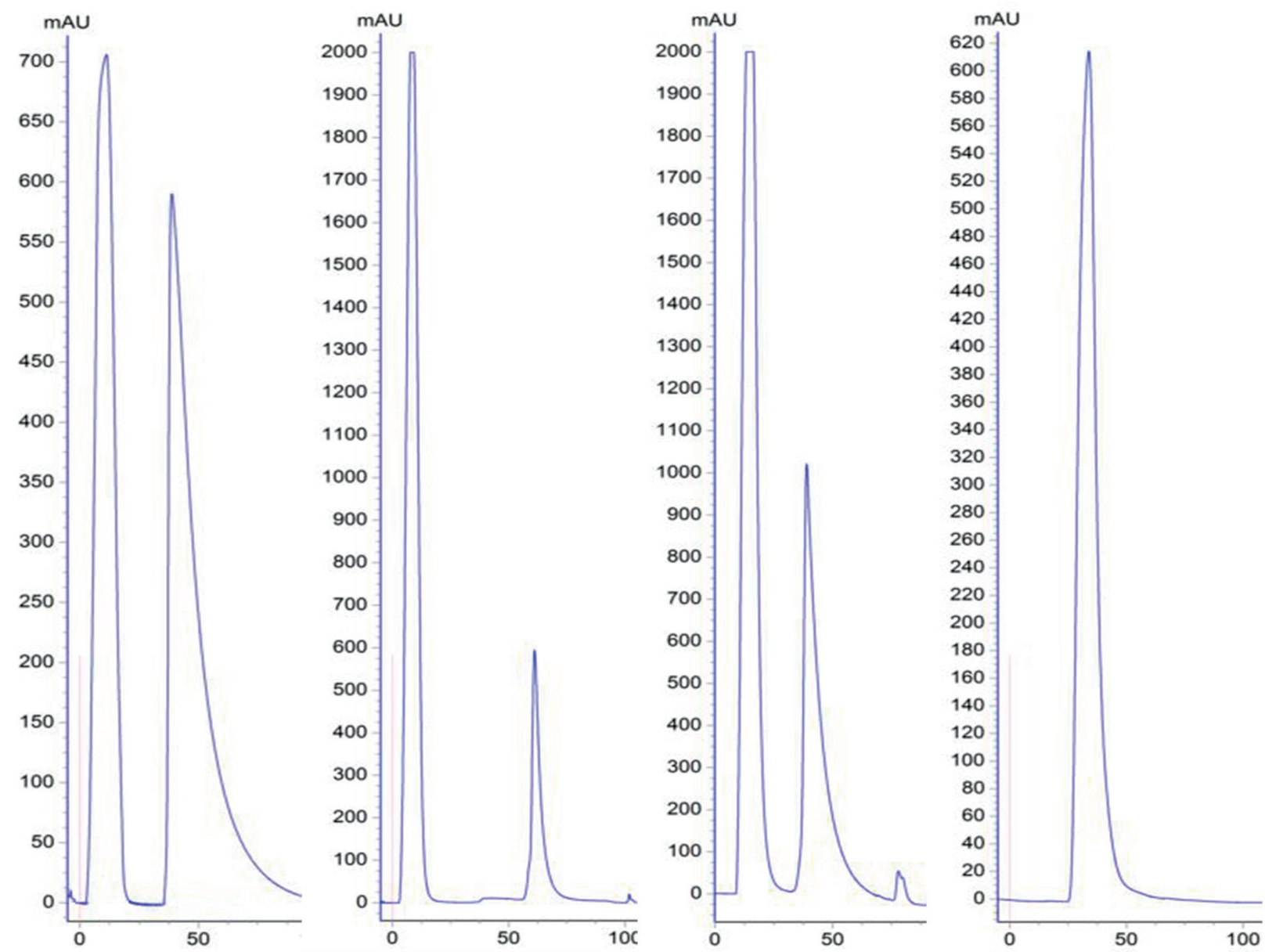
antibodies constitutes the basis for the purification of $\lg G, \lg G$ fragments and subclasses. The procedure typically employed for Protein A chromatography involves passage of clarified ascitic fluid or cell culture supernatant over the column at $\mathrm{pH}$ 6-8. Under these conditions the antibodies bind and unwanted components such as the ascites fluid contaminants or host cell proteins and cell culture media components flow through the column ${ }^{33}$

Protein A chromatography follows harvest, and yields a relatively pure product that only requires removal of a small proportion of process and product related impurities. One or two additional chromatography steps are employed as polishing steps, generally incorporating cationic and anionic exchange chromatography, although hydrophobic interaction chromatography, mixed mode chromatography or hydroxyapatite chromatography may be chosen as well. These steps provide additional clearance, removing aggregates, unwanted product variant species and other ascitic fluid contaminants ${ }^{34}$.

Because of its high selectivity, high flow rate and cost effective binding capacity and its capacity for extensive removal of process-related impurities, Protein A chromatography is typically used as the first step in an antibody purification process. After this step, the antibody product is highly pure and more stable due to the elimination of proteases and other media components that may cause degradation ${ }^{34}$

\section{MAbs characterization}

\section{Productivity}

Table 5. Productivity of purification process

\begin{tabular}{|c|c|c|}
\hline MAbs & Concentration $(\mathrm{mg} / \mathrm{mL})$ & Yield (mg/mL of ascites) \\
\hline 2B5B10 & 1,12 & 3,5 \\
\hline 2E4D11 & 1,44 & 3,0 \\
\hline 1D12E10 & 1,30 & 2,9 \\
\hline 1D1D11 & 1,03 & 3,7 \\
\hline $\mathbf{1 7 7 / 1 0 / 2 7 / 1 1}$ & 2,10 & 3,5 \\
\hline
\end{tabular}

The determination of total proteins in the desalted fraction allows calculate the productivity of the process. Protein concentration of purified MAbs and the yield are shown in Table 5 .

Different productivities justify the fact that ascites titration curves were not the same, as OD is a directly proportional measure of the quantity of MAbs in the sample. Also, specific fractions were not the same in both profiles, corroborating the differences between clones regarding the quantity of MAbs produced. Also it could be due to samples did not have the same quantity of cells, implying differences in the quantity of MAb produced. This fact is not descripted in the literature, is something proper of each clone. These values of productivity are considered high and are consistent with the results obtained by our group for the process of obtaining other MAbs ${ }^{16,17}$. It is described that ascites is a source of high concentration of MAbs (1-15 mg/mL $)^{27}$ while the culture supernatants of hybridomas are approximately a hundred or thousand times lower concentrated $(0.01-005 \mathrm{mg} / \mathrm{mL})^{35}$. In addition, the ascites fluid can be obtained easily and at a relatively low production cost, which is a good starting material for the production of non-therapeutic MAbs.

\section{Purity}

Antibodies purification resulted in highly purified MAbs. Figure 3 shows the electrophoretic profile by SDS-PAGE under reducing condition, of each fraction involved in the purification process of both MAbs.

The electrophoretic profiles of the SF collected in the purification process from every MAbs are very similar. Lane 2 correspond to the U.F not retained in the column during the affinity chromatography. In all cases, the U.F is characterized by the exclusive presence of contaminants, showing an efficient adsorption of MAbs to the Protein A matrix. Remaining lanes show the purified MAbs. The bands visualized correspond to the heavy chains $(50 \mathrm{kDa})$ and light chains $(25 \mathrm{kDa})$ of murine IgG. Figure 4 shows the results of the densitometric analysis and the purity.

Antibody-purity analysis is critical to successful development of monoclonal antibody (MAb) biopharmaceuticals. Determine the degree or percentage of purity of a MAb, is im-

Figure 3 Electrophoretic profile obtained by SDS-PAGE from the purification of MAbs. Lane 1: Low Molecular Weight Ladder. Lane 2: Unspecific fraction. Lane 3: 2B5B10. Lane 4: 2E4D11. Lane 5: 1D12E10. Lane 6: 1D1D11. Lane 7: 177/10/27/11.

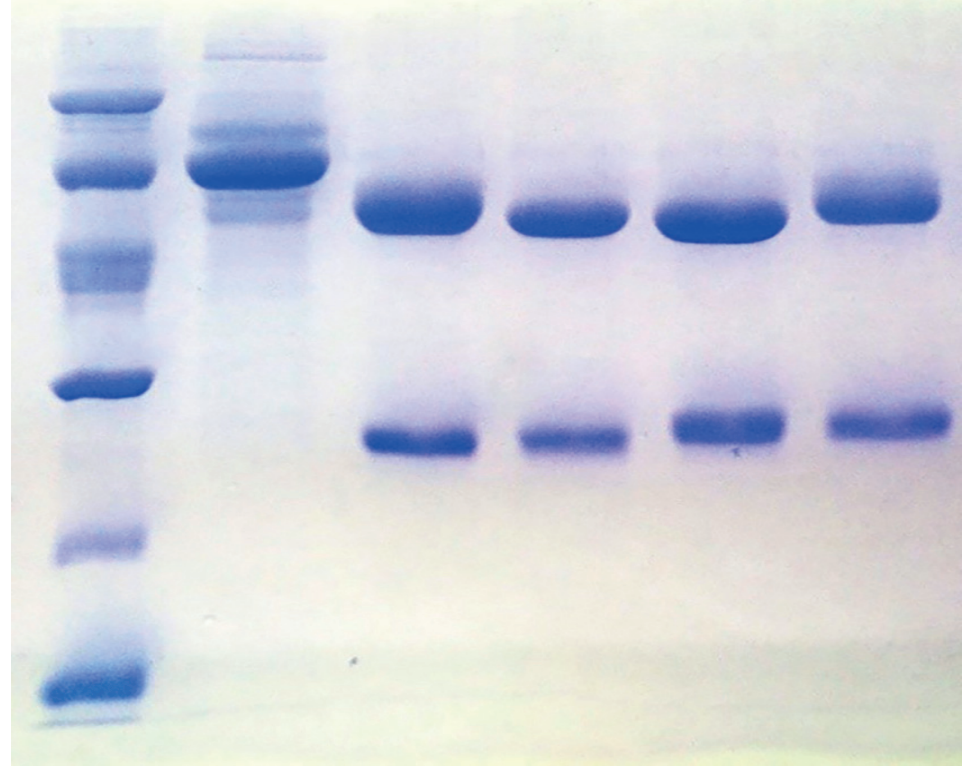




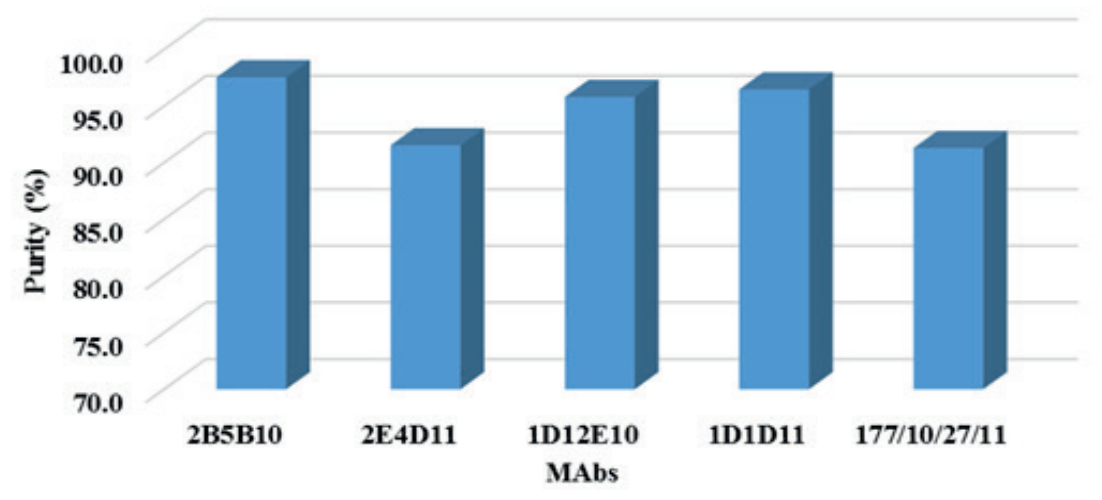

portant and gives us information about how efficient was the purification process used. As expected, by using protein A as ligand affinity chromatography, in the process of purification of both antibodies, high purity percentages were obtained (over 96\%). On the other hand, determine the percentage of purity is important also for the MAb applicability. For diagnostic purposes, it is often sufficient antibodies preparations with 70 to 95\% purity. For analytical purposes (as a standard reagent or for standardizing techniques to ensure quality control of a product), antibodies with a purity greater than 95\% are required. And finally for therapeutic purposes, particularly humanized antibodies, are preparations that demands a percentage of pu-

Table 6. Affinity constant (Kaff) determined by indirect ELISA

\begin{tabular}{|c|c|}
\hline MAbs & Kaff (M-1) \\
\hline 2B5B10 & $3.8 \times 10^{11}$ \\
\hline 2E4D11 & $1.5 \times 10^{12}$ \\
\hline 1D12E10 & $8.7 \times 10^{10}$ \\
\hline 1D1D11 & $1.4 \times 10^{13}$ \\
\hline $\mathbf{1 7 7 / 1 0} / \mathbf{2 7} / \mathbf{1 1}$ & $7.2 \times 10^{9}$ \\
\hline
\end{tabular}

rity greater than 99\% (36). Purity levels over 96\% are enough for the goals of this MAb in our lab (as analytical tool).

\section{MAbs affinity constant}

Kaff determined by indirect ELISA are shown in Table 6.

These values were similar to those reported by Reyes and colleagues for MAbs against $N$. meningitidis serogroups $A, C$, $Y, W$ and $X^{16,17}$. It was thought that many of the MAbs had low affinity for biological molecules and therefore they will not displace polyclonal antibodies as instruments. Nowadays, it has been demonstrated that, with a proper selection procedure, it is possible to obtain high affinity MAbs; that have become a very reliable and essential tools for immunoassays ${ }^{15-17}$.

Affinity measures the strength of interaction between an epitope and binding site in the antibody. It is defined by the same basic thermodynamic principles that govern any reversible biomolecular interaction ${ }^{22}$.

Kaff describes how much antibody-antigen complex exist at the point when equilibrium is reached. The time taken for this happen depends on rate of diffusion and is similar for every antibody. However, high-affinity antibodies will bind a greater amount of antigen in a shorter period of time than low-affinity antibodies. KA can therefore vary widely for antibodies from below $10^{5} \mathrm{M}^{-1}$ to above $10^{12} \mathrm{M}^{-1}$, and can be influenced by factors including $\mathrm{pH}$, temperature and buffer composition.

Knowing the Kaff of an antibody allows judicious selection of antibody for a specific purpose, such as using low affinity antibody in an affinity chromatography procedure for antigen purification ${ }^{37}$ or high-affinity antibody in immunoassay techniques $^{38}$. Employment of low affinity antibody in an immunoaffinity column would allow purification and elution of the bound antigen with a mild elution buffer avoiding protein denaturation. The use of a high affinity MAb, on the other hand, is regarded as a decisive factor for improvement of the sensitivity of an immunoassay, such as ELISA. So, based on the affinity of our MAbs, both could be used in identity and quantification methods of PS-14 in QuimiVio by ELISA, as Reyes made with the MAbs for PS from N. meningitidis.

\section{MAbs specificities}

Recognition and reactivity of purified MAbs were evaluated by an indirect ELISA assay. Figure 5 shows the results.

The graph shows that $\mathrm{OD}_{492 \mathrm{~nm}}$ values were elevated against the homologous PS for each MAb, showing that maintain its reactivity after purification and do not cross react with polysaccharides from other serogroups or tetanus toxoid (carrier).

In manufacture of multivalent vaccines, WHO and National Regulatory Agencies (CECMED in Cuba), establish a mandatory requirement for all final vaccine: the identity of all the active principles declared in the sample (39-41). For protein vaccines, for example, by SDS-PAGE the bands profile can be identified and establish the identity of the product, however in the case of the polysaccharide based vaccines that is not so easy.

For this purpose, nuclear magnetic resonance spectroscopy (RMN) (either $1 \mathrm{H}$ or $13 \mathrm{C}$ ) and/or serological method such as counter current immunoelectrophoresis provide convenient methods for the confirmation of identity of purified polysaccharide (14). However, NMR is a complicated and expensive technology and does not work for the conjugate polysaccharides due to the addition of a protein carrier; while preparation of monospecific antisera can be a costly and time-consuming activity.

\section{Conclusions}

Monoclonal antibodies (MAbs) have been obtained mainly as serogrouping reagents and have been used in identity test 
Figure 5. Cross reactivity of MAbs against different PS from other serotypes of S. pneumoniae.

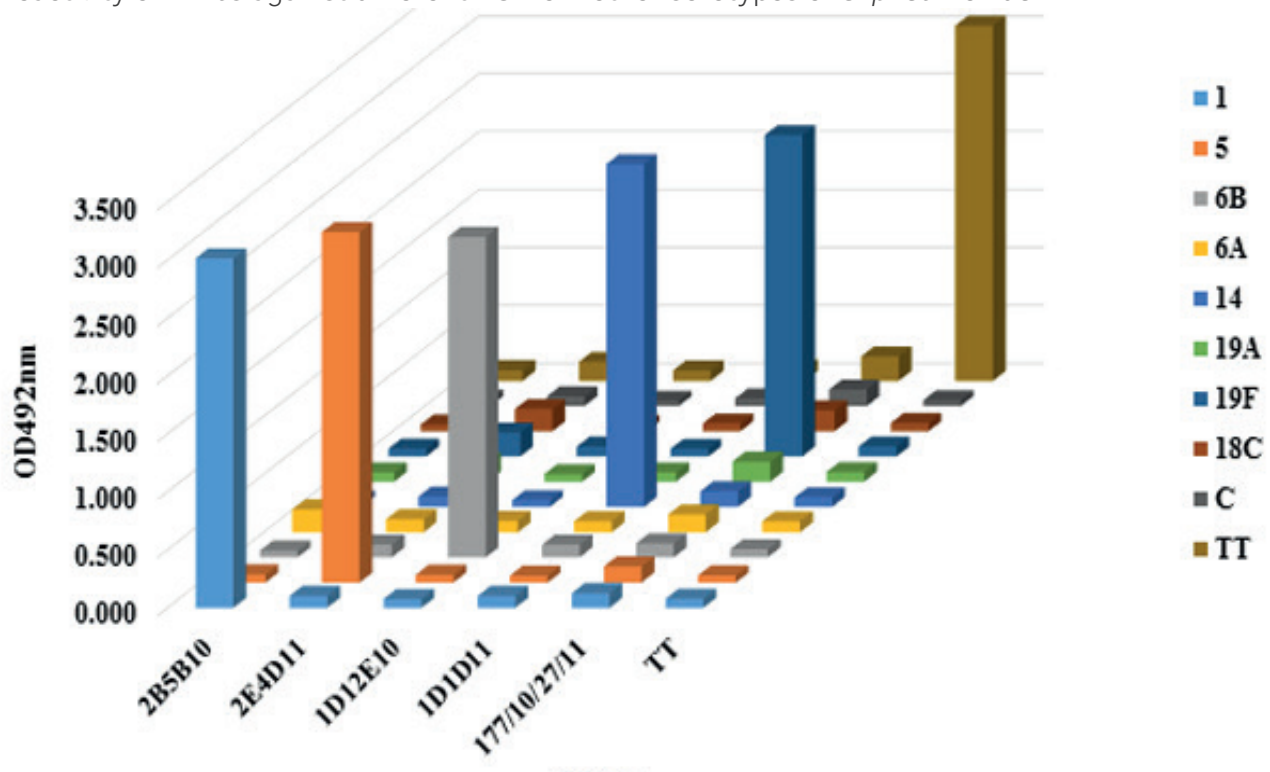

for other multivalent polysaccharide based vaccines ${ }^{16,17}$. Having MAbs capable of identify in a multivalent formulation only their homologous PS and discriminate between compounds of related structure is a great tool for analytical assays. These results confirm the feasibility of using these MAbs in identity tests of multivalent vaccines.

\section{Bibliographic references}

1. Simell B, Auranen K, Käyhty H, Goldblatt D, Dagan R, O'Brien KL. The fundamental link between pneumococcal carriage and disease. Expert review of vaccines. 2012;11(7):841-55.

2. Walker CLF, Rudan I, Liu L, Nair H, Theodoratou E, Bhutta ZA, et al. Global burden of childhood pneumonia and diarrhoea. The Lancet. 2013:381(9875):1405-16

3. O'Brien KL, Wolfson LJ, Watt JP, Henkle E, Deloria-Knoll M, McCall $\mathrm{N}$, et al. Burden of disease caused by Streptococcus pneumoniae in children younger than 5 years: global estimates. The Lancet. 2009;374(9693):893-902.

4. Perciani CT, Barazzone GC, Goulart C, Carvalho E, Cabrera-Crespo J, Gonçalves VM, et al. Conjugation of polysaccharide $6 B$ from Streptococcus pneumoniae with pneumococcal surface protein $A$ : PspA conformation and its effect on the immune response. Clinical and Vaccine Immunology. 2013;20(6):858-66.

5. Thomas JC, Figueira M, Fennie KP, Laufer AS, Kong Y, Pichichero ME, et al. Streptococcus pneumoniae clonal complex 199: genetic diversity and tissue-specific virulence. PLoS One. 2011;6(4):e18649.

6. Liñares J, Ardanuy C, Pallares R, Fenoll A. Changes in antimicrobial resistance, serotypes and genotypes in Streptococcus pneumoniae over a 30-year period. Clinical Microbiology and Infection. 2010;16(5):402-10.

7. Weinberger DM, Malley R, Lipsitch M. Serotype replacement in disease after pneumococcal vaccination. The Lancet. 2011:378(9807):1962-73.

8. Spijkerman J, van Gils EJM, Veenhoven RH, Hak E, Yzerman F, van der Ende A, et al. Carriage of Streptococcus pneumoniae 3 Years after Start of Vaccination Program, the Netherlands. Emerging Infectious Diseases. 2011;17(4):584-91.

9. Lee GM, Kleinman K, Pelton SI, Hanage W, Huang SS, Lakoma M, et al. Impact of 13-valent pneumococcal conjugate vaccination on Streptococcus pneumoniae carriage in young children in Massachusetts. Journal of the Pediatric Infectious Diseases Society. 2013:pit057.

10. Toraño Peraza GT, Llanes Caballero R, Pías Solis LM, Abreu Capote M, Valcárcel Sánchez M. Serotipos de Streptococcus pneumoniae en Cuba y progresión de la resistencia a la penicilina. Revista Cubana de Medicina Tropical. 2010;62:157-60.

11. Gilda Teresa TP, Lisania P, Miriam A, Misladys R, Félix D, Marlen $V$, editors. Serotipos y resistencia antimicrobiana de aislamientos meníngeos de Streptococcus pneumoniae, Cuba, 2007-2012. 8th Cuban Congress on Microbiology and Parasitology, 5th National Congress on Tropical Medicine and 5th International Symposium on HIV/aids infection in Cuba; 2014

12. Frasch CE. Preparation of bacterial polysaccharide-protein conjugates: Analytical and manufacturing challenges. Vaccine. 2009:27(46):6468-70.

13. Organization WH. Recommendations to assure the quality, safety and efficacy of pneumococcal conjugate vaccines. Proposed replacement of TRS. 2009;927.

14. Standardization WECoB. Recommendations to Assure the Quality, Safety, and Efficacy of Pneumococcal Conjugate Vaccines: Proposed Replacement of : TRS 927, Annex 2: World Health Organization: 2009

15. Reyes F, Otero O, Cuello M, Amin N, García L, Cardoso D, et al. Development of four sandwich ELISAs for quantitation of capsular polysaccharides from Neisseria meningitidis serogroups A, C, W and $Y$ in multivalent vaccines. Journal of immunological methods. 2014;407:58-62.

16. Reyes F, Amin N, Otero O, Aguilar A, Cuello M, Valdés Y, et al. Four monoclonal antibodies against capsular polysaccharides of Neisseria meningitidis serogroups $A, C, Y$ and $W_{135}$ : Its application in identity tests. Biologicals. 2013

17. Reyes F, Otero O, Camacho F, Amin N, Ramírez F, Valdés Y, et al. A novel monoclonal antibody to Neisseria meningitidis serogroup $X$ capsular polysaccharide and its potential use in quantitation of meningococcal vaccines. Biologicals. 2014;42(6):312-5.

18. Council NR. Guide for the Care and Use of Laboratory Animals: Eighth Edition. Washington, DC: The National Academies Press; 2011. $248 \mathrm{p}$.

19. Köhler G, Milstein C. Continuous cultures of fused cells secreting antibody of predefined specificity. nature. 1975;256:495-7.

20. Smith PK, Krohn RI, Hermanson G, Mallia A, Gartner F, Provenzano $\mathrm{M}$, et al. Measurement of protein using bicinchoninic acid. Analytical biochemistry. 1985;150(1):76-85.

21. Laemmli UK. Cleavage of structural proteins during the assembly of the head of bacteriophage T4. nature. 1970;227:680-5. 
22. Beatty JD, Beatty BG, Vlahos WG. Measurement of monoclonal antibody affinity by non-competitive enzyme immunoassay. Journal of Immunological Methods. 1987;100(1-2):173-9.

23. Ward P, Adams J, Gebhart G. Monoclonal antibody production: a report of the committee on methods of producing monoclonal antibodies. Institute for Laboratory Animal Research, National Research Council. 1999:9-23.

24. McArdle J. Alternatives to ascites production of monoclonal antibodies. Animal Welfare Information Center newsletter (USA). 1997.

25. Brijesh K, Gadhvi V, Gupta A, Roopchandani K, Patel N. A Review: Production of Monoclonal Antibody. Research Journal of Pharmacy and Technology. 2013;6(7):701-5.

26. Leenaars M, Hendriksen CF. Critical steps in the production of polyclonal and monoclonal antibodies: evaluation and recommendations. Ilar Journal. 2005;46(3):269-79.

27. Kabir S. Immunoglobulin purification by affinity chromatography using protein A mimetic ligands prepared by combinatorial chemical synthesis. Immunological investigations. 2002;31(3-4):263-78.

28. Peterson NC. Advances in monoclonal antibody technology: genetic engineering of mice, cells, and immunoglobulins. ILAR journal. 2005;46(3):314-9.

29. Healthcare GE. Antibody Purification Handbook2002-2015. 48- p.

30. Scopes R. Protein Purification Principles and Practice 3rd Edition (Cantor CR ed) pp. 270-277 Springer-Verlag. New York. 1994.

31. Janson JC. Protein Purification: Principles, High Resolution Methods, and Applications: Wiley; 2012.

32. Fahrner RL, Knudsen HL, Basey CD, Galan W, Feuerhelm D, Vanderlaan $\mathrm{M}$, et al. Industrial purification of pharmaceutical antibodies: development, operation, and validation of chromatography processes. Biotechnology and Genetic Engineering Reviews. 2001;18(1):301-27.
33. Birch JR, Racher AJ. Antibody production. Advanced drug delivery reviews. 2006;58(5):671-85.

34. Liu HF, Ma J, Winter C, Bayer R, editors. Recovery and purification process development for monoclonal antibody production. MAbs; 2010: Taylor \& Francis.

35. Juronen E, Parik J, Toomik P. FPLC purification of mouse monoclonal antibodies from ascitic fluid using blue DEAE and thiophilic sorbents. Journal of immunological methods. 1991;136(1):103-9.

36. Gottschalk U. Downstream processing of monoclonal antibodies: from high dilution to high purity. Biopharm international. 2005;18(6):42-58.

37. Van Heyningen V, Barron L, Brock D, Crichton D, Lawrie S. Monoclonal antibodies to human $囚$-foetoprotein: analysis of the behaviour of three different antibodies. Journal of immunological methods. 1982;50(2):123-31

38. Steward MW, Lew AM. The importance of antibody affinity in the performance of immunoassays for antibody. Journal of immunological methods. 1985;78(2):173-90.

39. CECMED. Requisitos para la liberación de lotes de vacunas. Regulación No.19. 2000.

40.Organization WH. Vaccine and immunization, quality and safety 2004.

41. OMS. Manual de entrenamiento: concesión de licencias, liberación de lotes y disponibilidad de laboratorio. Vacunas y productos biológicos. 2003.

Recibido: 31 october 2017

Aprobado: 29 december 2017 